\title{
Physicochemical and Bacteriological Assessment of Tannery Effluent from Samaru - Zaria, Kaduna State, Nigeria
}

\author{
*11MOHAMMED, SSD; ORUKOTAN, AA; ABDULLAHI, H
}

\author{
Department of Microbiology, Faculty of Science, Kaduna State University, Kaduna \\ *Corresponding Author:mosada78@yahoo.com or mohammed.sambo@kasu.edu.ng, Tel:+234(0)8035861774
}

\begin{abstract}
Physicochemical and bacteriological assessment of tannery effluent from Samaru -Zaria was carried out. A total of six (6) tannery effluent samples (from site A- point of discharge, site B- $20 \mathrm{~m}$ from point of discharge, site C- $40 \mathrm{~m}$ from point of discharge, site D$60 \mathrm{~m}$ from point of discharge, site E- $80 \mathrm{~m}$ from point of discharge and site F- $100 \mathrm{~m}$ from point of discharge) were collected from the Nigerian Leather and Science Technology, Samaru Zaria, Kaduna State in sterile labeled screw capped bottles. Physicochemical and bacteriological analysis was carried out using standard techniques. The physicochemical analysis revealed the appearance of the effluent to be dark-brown with unpleasant odour. the effluent further revealed the presence and at different concentrations of total solids, total suspended solids, total dissolved solids, total hardness, magnesium, sodium, potassium, iron, manganese, nitrite, nitrate, chloride, fluoride, sulphate, phosphate, cadmium, zinc and copper, chemical oxygen demand (COD), biological oxygen demand (BOD), oil and grease all in $\mathrm{mg} / \mathrm{L}$ except $\mathrm{pH}$. Bacillus sp had percentage occurrence of $100 \%$, Pseudomonas sp had $83.3 \%$, Flavobacterium, Micrococcus and Staphylococcus sp had 66.7\% each, Proteus and Klebsiella sp had 50.0\% occurrence each, Streptococcus had 33.3\% while Escherichia coli had the least percentage of occurrence of 16.7 from the samples of the tannery effluent analyzed respectively. The highest viable count was observed from site $\mathrm{F}$ which is $100 \mathrm{~m}$ away from the point of discharge and had $4.09 \times 10^{7} \mathrm{cfu} / \mathrm{ml}$ and the lowest from site A (point of discharge) with $1.2 \times 10^{7} \mathrm{cfu} / \mathrm{ml}$. The treatment of tannery effluents before discharge into the environment is necessary using biotreatment. This will reduce or eliminate environmental pollutions which could be detrimental to humans, animal s and plants. (C) JASEM
\end{abstract}

\section{https://dx.doi.org/10.4314/jasem.v21i4.14}

Keywords: Physicochemical, bacteria, COD, BOD, effluent

Tanning is the treatment of hides and skins to preserve and convert them into a stable material (leather) which will not putrefy and is suitable for a wide variety of applications (Akpomie, 2013). The beam house is where the preparatory processes for tanning ensure while the tanyard is actually where the leathers are produced (Akpomie, 2013).

All these processes occur in the tannery. The tanning process generates wastes that are of serious environmental impact particularly in countries where environmental regulations are not sufficiently strict. The used and non-useable hides and skins along with the excess process chemicals and water constitute solid and liquid wastes in the tannery (Mingshu et al., 2006). These wastes when untreated affect streams, groundwater, land and sewers in which they are discharged, this discharge of untreated wastewater in water courses affect the physical, chemical and biological characteristics of water and deplete the water bodies of dissolved oxygen (Rajiv et al., 2012).
Tannery waste is generated in huge amount during the process of tanning by leather industries throughout the world. It is considered one of the most polluted industrial wastes and contains high amount of metals which are very toxic to plants, animals and soil (Akpomie, 2013). Less than 5\% of industries in the world have adopted the adequate measure for treatment of effluent while most have neglected it because of cost implications. When tannery wastes gain access to cultivable lands or when the lands are irrigated with such wastes, the fertility of the soil is affected (Akpomie, 2013). Tanney wastes are known to reduce germination, growth and yield of grain, wheat and lettuce crops (Castilloss et al., 2007). It has also been reported that plant uptake metals such as chromium from tannery wastes and become available in roots, shoots, leaves, flowers and fruits with the minimum in fruits (Hussain et al.,. 2010). The diverse biochemical nature of microorganisms make it possible for them to metabolize most organic compounds found in industrial wastes hence constitute the basic biological units in tannery 
effluent treatment system (Akpomie, 2013). Microorganisms have been reported to remove some of the waste constituents, phenol was completely degraded, within 57.5 hours and 93.1hours using Pseudomonas resinovorans and Brevibacillus sp, respectively . Aspergillus niger was also isolated which is capable of producing tannase which was able to degrade tannin, a major constituent of tannery effluent (Murugan et al., 2011). Microbial biochemical process plays useful roles in the safe disposal of tannery waste. These processes are influence by $\mathrm{pH}$, temperature, nutrient availability, biomass behavior and concentration. Organisms in the tannery effluents have been reported to adopt measures that enable them tolerate and utilize the hazardous constituents of tannery effluents. Such measures include acquisition of plasma (Akpomie, 2013). Indigenous organisms thus are well adopted for the treatment of tannery effluent.

On the other hand, tannery effluent is the source of diverse extremophilic microbial flora, which has amazing adaptation and flexibility for surviving in extreme tannery environment. These microorganisms have ability to protect themselves from heavy metal toxicity by various mechanisms such as adsorption uptake, methylation, oxidation and reduction (Abhilasha, 2014).Tanneries generate wastewater in the range of $30-35 \mathrm{~L} / \mathrm{kg}$ skin / hide processed with variable $\mathrm{pH}$ and high concentrations of suspended solids, BOD, COD, tannins including chromium (Nazer et al., 2006) at about 30-35 L of water to $1 \mathrm{~kg}$ of processed skin (Suresh et al., 2001; Sreeram and Ramasami, 2003). With the present annual global processing capacity of $9 \times 109 \mathrm{Kg}$ hides and skins, it is estimated that $30-40 \times 1010$ litres of liquid effluent is generated (Thanikaivelan et al., 2004). This research is aimed at physico-chemical analysis and bacteriological assessment of tannery effluent from Samaru -Zaria town, Kaduna State.

\section{MATERIALS AND METHODS}

Collection of Samples: Six (6) tannery effluent samples from sites: Site A- point of discharge, site B- $20 \mathrm{~m}$ from point of discharge, site C- $40 \mathrm{~m}$ from point of discharge, site $\mathrm{D}-60 \mathrm{~m}$ from point of discharge, site E- $80 \mathrm{~m}$ from point of discharge and site F- $100 \mathrm{~m}$ from point of discharge were collected aseptically using sterile screw capped bottles from the tannery effluent disposal site which were brought back to the laboratory and was stored in the refrigerator as $4^{\circ} \mathrm{C}$ for bacteriological analysis.

Media Preparations: The media used for the research was nutrient agar and plate count agar which were prepared according to the manufacturer's instructions.

Determination of physicochemical Parameters of the Tannery Effluents: The tannery effluent samples were analyzed for their physicochemical parameters/properties such as appearance, odour, turbidity, total solids, total suspended solids, total dissolved solids, , $\mathrm{pH}$, total hardness, magnesium, sodium, potassium, iron, manganese, nitrite, nitrate, chloride, fluoride, sulphate, phosphate, chemical oxygen demand (COD), biological oxygen demand (BOD), oil and grease. Heavy metals such as cadmium zinc and copper using the method described by Arasappan and Kalyanaraman (2015).

Microbiological Analysis of the Tannery Effluents: Determination of Total Viable Counts of Bacteria in the Effluents: Serial dilution of the effluent samples were prepared by transferring aseptically $1 \mathrm{ml}$ of the effluent in $9 \mathrm{~m} 1$ of distilled sterile water contained in a sterile test tubes until the desired dilution of $10^{6}$ was reached for each sample respectively. The $10^{6}$ dilution of each sample were pour plated on plate count agar (PCA) for enumeration of isolates, Nutrient agar for bacterial isolation. All plates were in triplicate for each sample respectively. The inoculated plate of plate count agar (PCA) and Nutrient agar (NA) were incubated at $37^{\circ} \mathrm{C}$ for 24 hours. After 24 hours of incubation, the isolates of different morphology were transferred aseptically sub-cultured onto a newly prepared nutrient agar plate using streak plate's method. The plates were incubated at $37^{\circ} \mathrm{C}$ for 24 hours. Pure cultures were stored on agar slants for further studies.

Characterization and Identification of Bacteria from the Tannery Effluents: The biochemical tests of each isolate were carried out using standard methods as described by Oyeleke and Manga (2008); Cheesbrough (2004). The biochemical tests include: Gram's staining, catalase test, coagulase test, indole test, motility test, urease test, Methyl Red Voges Proskauer Test (MR-VP) and triple sugar iron test.

\section{RESULTS AND DISCUSSION}

The results of the physicochemical parameters of the effluents are presented in Table 1.The result revealed the appearance of the effluent to be dark-brown with unpleasant odour. the effluent further revealed the presence and at different concentrations of total solids, total suspended solids, total dissolved solids, total hardness, magnesium, sodium, potassium, iron, manganese, nitrite, nitrate, chloride, fluoride, sulphate, phosphate, cadmium, zinc and copper, chemical oxygen demand (COD), biological oxygen demand (BOD), oil and grease in $\mathrm{mg} / \mathrm{L}$ except $\mathrm{pH}$ 
(Table 1). The results in Table 2 Shows the comparative mean aerobic colonial count obtained from tannery effluent from samaru- zaria town. Fig 1 revealed the morphological and biochemical characteristics of different bacteria isolates of tannery effluent obtained from site A to F. The organisms isolated were Staphylococcus sp, Pseudomonas sp, Eschericia sp and Bacillus sp from site A.. Site B of tannery effluent had organisms such as Proteus sp, Micrococcus sp, Bacillus sp, Pseudomonas sp and Klebsiella sp while site $\mathrm{C}$ of the tannery effluent analyzed had bacteria isolates such as Flavobacterium sp, Bacillus sp, Klebsiella, sp, Pseudomonas sp, and Micrococcus sp. The site D of the tannery effluent had bacteria isolates such as Pseudomonas sp, Flavobacterium sp, Proteus sp, Bacillus sp, Staphyloccous sp and Micrococcus sp. Streptococcus sp, Bacillus sp, Flavobacterium sp, and Staphylococcus sp were isolated from site E of the tannery effluent. Site F of the tannery effluent had bacteria isolates such as Bacillus sp, Pseudomonas sp, Proteus sp, Klebsiella sp, Micrioccus sp and Streptococcus sp (Fig 1). Bacillus sp had percentage occurrence of $100 \%$, Pseudomonas sp had $83.3 \%$, Flavobacterium, Micrococcus and Staphylococcus sp had $66.7 \%$ each, Proteus and Klebsiella sp had $50.0 \%$ occurrence each, Streptococcus had $33.3 \%$ and Escherichia coli had the least percentage of occurrence of 16.7 from the samples of the tannery effluent analyzed respectively (Fig 2).

The physicochemical parameters revealed that colour of the untreated effluent were dark-brown with offensive/ unpleasant odour. Similar results were reported by Noorjahan (2014) who also observed dark-brown colour with offensive odour of the untreated effluent. The colour of the effluent might be due to the presence of biodegradable and high molecular weight organic compounds and high amount of inorganic chemicals like sodium and chromium used during the processing and the odour may be due to putrefaction of the organic residues from the processed skin and hides. Similar report was revealed by Smrithi and Usha in 2012. The presence of the solid impurities could be the cause of turbidity in the effluent. The composition of solids present in tannery effluent mainly depends upon the nature and quality of hides and skins processed in the tannery. This is similar to the findings of Islam et al. (2014). Total dissolved solids in the effluent samples could be mainly due to presence of bicarbonates, carbonates, chlorides, sulphates, phosphates, nitrates, nitrogen, calcium, sodium, potassium and iron in the chemicals used in the processing of the hides and skin. This agrees with the report of Kannan et al.
(2009). Sulphate is a component of tannery effluent, emanating from the use of sulphuric acid or products with a high (sodium) sulphate content. There was increase in the BOD of the effluent analyzed. Increase in BOD which is a reflection of microbial oxygen demand leads to depletion of Dissolved Oxygen (DO) which may cause hypoxia conditions with consequent adverse effects on aquatic biota. Increased in COD was observed, this could be as a result of the presence of some organic compounds in the effluent. The increased amount of COD may be due to high amount of organic compounds which are not affected by the bacterial decomposition ( Nagarajan and Ramachandramoorthy, 2002). The bacteriological research findings indicated that Bacillus sp, Pseudomanas sp., streptococcus sp., Staphylococcus sp., Escherichia coli, Proteus sp., micrococcus sp., Flavobacterium sp., and Klebsiella sp were the bacterial isolates associated with tannery effluent Zaria town, Kaduna State. In which Pseudomonas sp., Bacillus sp., Flavobacterium, Staphylococcus sp., Micrococcus and Klebsiella were the major isolates. This is in agreement with the findings of Mohammed et al. (2001) who isolated similar bacteria but reported that Klebsiella sp., Bacillus sp and Pseudomonas sp were the major bacteria isolated from tannery effluent. Organisms in the tannery effluent have been reported to adopt measures that enable them tolerate and utilize the hazardous constituents of tannery effluents. Such measures include acquisition of plasma (Mythili and Karrhikeyan, 2011). The growth of those organisms in the tannery effluent contaminant toxic substances such as chromium which otherwise should have inhibited the growth of microorganism can be attributed to the ability of the organisms to acquire variety of adaptation to the organisms to acquire variety of adaptation to the present of some of the toxic components of the tannery effluent. The viable colonial count $(\mathrm{CFU} / \mathrm{ml})$ of the tannery effluent at different site (A, B,C, D, E and F), site A had the least colony count of $1.20 \times 10^{7}$ whereas site $\mathrm{F}$ which is $400 \mathrm{~m}$ away from site $\mathrm{A}$, had the highest colony count of $4.09 \times 10^{7}$. This might be as a result of the concentration of presence of chromium in site A which is higher than site $\mathrm{F}$. The chromium which is a heavy metal in the tannery effluent may be responsible for the low number of microorganisms recorded at site A. Bacillus had $100 \%$ percentage occurrence, Pseudomonas had $83.3 \%$ Flavobacterium sp., Micrococcus 56\%, and Staphylococcus sp had $66.7 \%$, Proteus sp and Klebsiella sp had 50\% each, Streptococcus sp had $33.3 \%$ where as the least which was Escherichia coli with $16.7 \%$ from all site samples analyzed. This agrees with the findings of Akpomie (2013) who 
reported that Bacillus sp and Pseudomonas were the predominant organisms and micrococcus sp., Proteus sp and Klebsiella were subdominant in tannery effluent in Kano state Nigeria. Bacillus sp and Pseudomonas sp, having $100 \%$ and $83.3 \%$ occurrence in the tannery effluent might be due to the ability of the organisms to acquire a variety of adaptations to the presence of some of the toxic components of the tannery effluent (Selvi et al., 2013). And also due to the inherent facility to form spores possessing tough outer cover which facilities their survival (Akpomie, 2013).. Pseudomonas sp are regarded as one of the most common species of bacteria degrading phenol compounds isolated from contaminated sites of different industries (and also are promising bacteria found in water and soil and also recognized in the degradation of non conventional compounds and useful in environmental bioremediation (Amna and Fozia, 2012). The bacteria predominant in different industrial effluent are largely derived from water causes basically; the bacteria are responsible for the degradation of organic and inorganic compounds. They derive their nutritional requirement from the compounds presented to them in the effluent waste. They are able to synthesize their enzymes, metabolic intermediates, structural proteins, lipids and nucleic acids from carbon compounds in the feed, together with other element. They derive their energy from oxidizing either organic compounds (Chemoorganotrophic metabolism) or inorganic compounds (chemoorganotrophic metabolism) such as reduced sulfur or nitrogen compound. They use the energy for their bodily functions reproduction and growth (Amna and Fozia., 2012). The least percentage occurrence of bacterial was Escherichia coli with $16.3 \%$. They normally reside in the intestine of animals find their way into the hides and skins during slaughtering. This is in agreement with Yapici (2008) who reported the presence of $E$. coli in effluents and attributed their presence in intestine and skin of animals. Pseudomonas sp and Bacillus sp are resistance to heavy metals as they are able to survive and adapt to the toxic composition of the tannery effluent. Escherichia coli and Bacillus sp could reduce the presence of chromium from the tannery effluents as observed in this study. Several gram positive bacteria were known to reduce chromium including several members of the genera Bacillus sp as reported by Camargo et al. (2003).

Table 1: Some Physicochemical Parameters of Untreated Tannery Effluents from Zaria

\begin{tabular}{ll}
\hline Parameters & Untreated effluents \\
\hline Appearance & Brown \\
Odour & Unpleasant \\
Turbidity NTU & 26.7 \\
Total Solids $(\mathrm{mg} / \mathrm{L})$ & 566.8 \\
Total Suspended Solids $(\mathrm{mg} / \mathrm{L})$ & 501 \\
Total Dissolved Solids $(\mathrm{mg} / \mathrm{L})$ & 532.7 \\
pH & 6.89 \\
Total Hardness $\left(\right.$ as $\left.\mathrm{CaCO}_{3}\right)(\mathrm{mg} / \mathrm{L})$ & 1451.6 \\
Magnesium $(\mathrm{mg} / \mathrm{L})$ & 142.3 \\
Sodium $(\mathrm{mg} / \mathrm{L})$ & 17.8 \\
Potassium $(\mathrm{mg} / \mathrm{L})$ & 312.6 \\
Manganese $(\mathrm{mg} / \mathrm{L})$ & 3.00 \\
Iron $(\mathrm{mg} / \mathrm{L})$ & 15.6 \\
Chloride $(\mathrm{mg} / \mathrm{L})$ & 1011.2 \\
Nitrite $(\mathrm{mg} / \mathrm{L})$ & 1.0 \\
Nitrate $(\mathrm{mg} / \mathrm{L})$ & 12.0 \\
Sulphate $(\mathrm{mg} / \mathrm{L})$ & 1522 \\
Phosphate $(\mathrm{mg} / \mathrm{L})$ & 2.2 \\
COD $(\mathrm{mg} / \mathrm{L})$ & 2.2 \\
BOD $(\mathrm{mg} / \mathrm{L})$ & 1032 \\
Chromium $(\mathrm{mg} / \mathrm{L})$ & 0.0325 \\
Copper $(\mathrm{mg} / \mathrm{L})$ & 1.0092 \\
Zinc $(\mathrm{mg} / \mathrm{L})$ & 1.2333 \\
Lead $(\mathrm{mg} / \mathrm{L})$ & 0.7663 \\
Oil and grease $(\mathrm{Mg} / \mathrm{L})$ & 0.02 \\
\hline
\end{tabular}

*All values are in $(\mathrm{Mg} / \mathrm{L})$ except Appearance, Odour, and $\mathrm{pH}$ 
Table 2: Mean Aerobic Bacteria Colonial Counts from Tannery Effluents Sample Sites Mean bacterial count $(\mathrm{Cfu} / \mathrm{ml})$

\begin{tabular}{ll}
\hline $\mathrm{A}$ & $1.2 \times 10^{7}$ \\
$\mathrm{~B}$ & $1.4 \times 10^{7}$ \\
$\mathrm{C}$ & $2.0 \times 10^{7}$ \\
$\mathrm{D}$ & $2.32 \times 10^{7}$ \\
$\mathrm{E}$ & $3.69 \times 10^{7}$ \\
$\mathrm{~F}$ & $4.09 \times 10^{7}$ \\
& \\
\hline
\end{tabular}

Site A-Point of discharge; B-20 m from the point of discharge; C-40 m from the point of discharge; D-60 m from the point of discharge; E- $80 \mathrm{~m}$ from the point of discharge; F-100 $\mathrm{m}$ from the point of discharge.

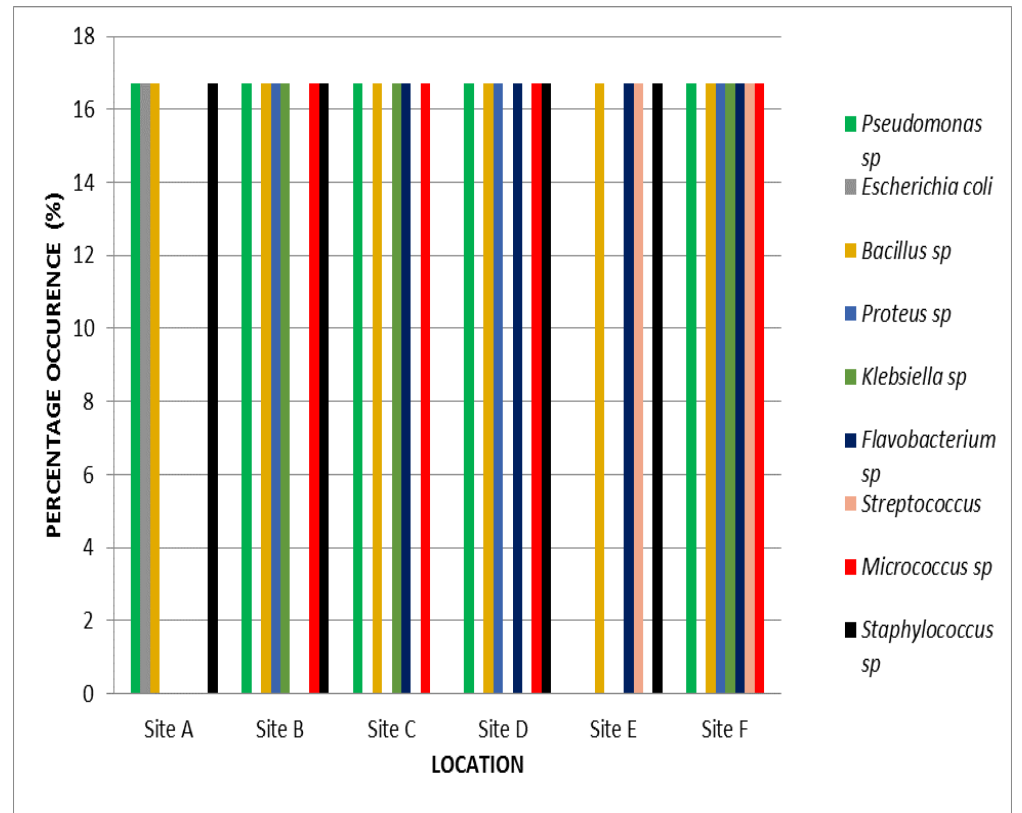

Fig 1: Occurrence of Bacterial Isolates from Tannery Effluent from Samaru- Zaria 


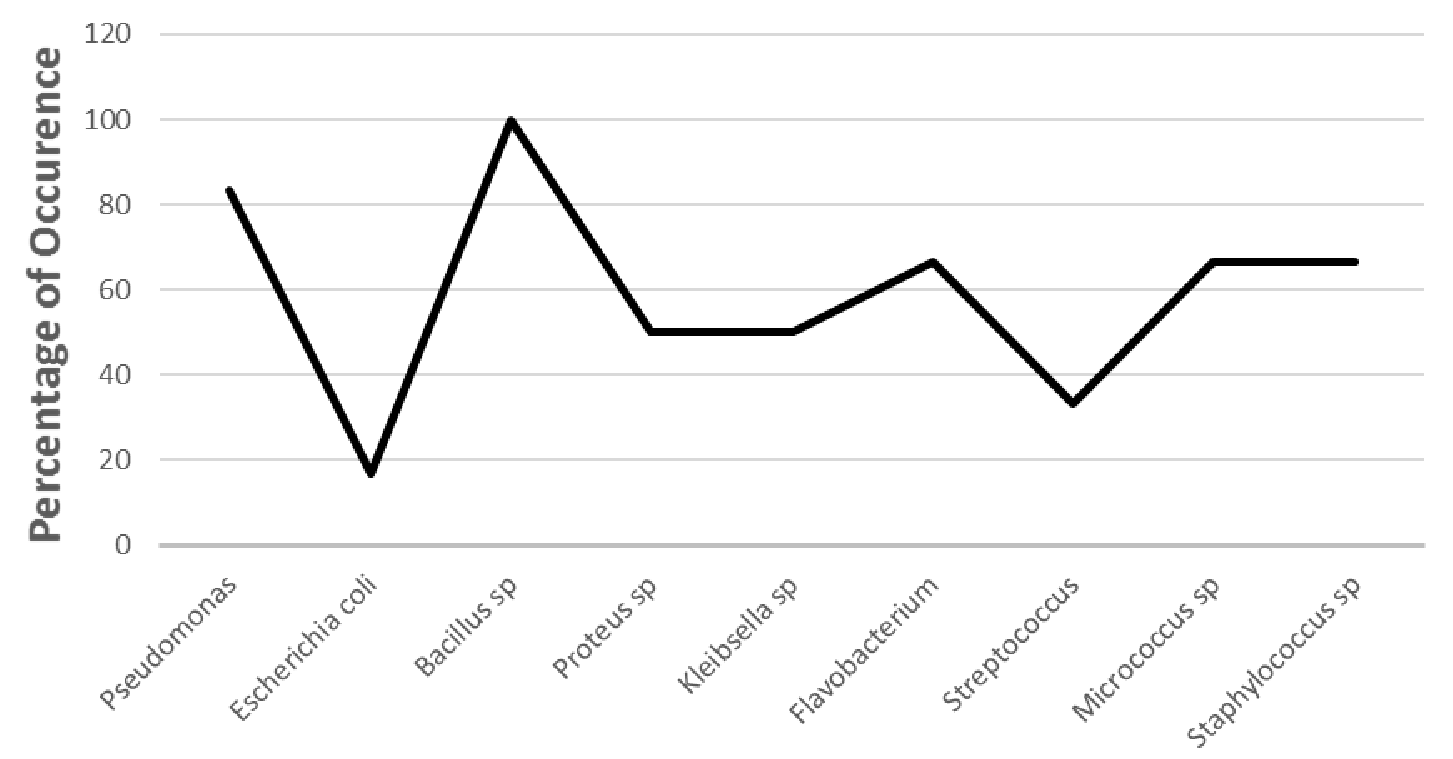

Bacteria Isolates

Fig 2: Percentage Occurrence of Microbial Isolates from Tannery Effluent Sampling Sites

Conclusion: These research findings revealed the presence of some physicochemical parameters and bacteria species such as Streptococcus, Staphylococcus, Bacillus, Pseudomonas, Micrococcus, Klebsiella, Proteus, Escherichia coli and Staphylococcus from the tannery effluent analyzed. Bacillus sp and Pseudomonas sp were the predominant bacteria isolated and identified. This indicate that the frequent occurrence of Bacillus and Pseudomonas sp in all samples analyzed could be as a result of their ability to survive and resist chromium and other heavy metals present in the tannery effluent.

Acknowledgements: The authors of this research acknowledged the efforts of the laboratory staff of the Department of Microbiology, Faculty of Science, Kaduna State University, Kaduna towards the success of this work.

\section{REFERENCES}

Amna, A; Fozia, N (2012). Frequency Distribution of Bacteria Isolated from Different Industrial Effluent. Daffodil International Journal of Science and Technology.7.12-16.

Akpomie, O O (2013). Optimization and Characterization of Indigenous Microorganisms Isolated from Tannery Effluents in Nigeria. Intl. J. Environ. Sci.2(10):14-21.
Castilloss, CSC; Rangel ,AO;Castro, PMC (2007). Constmeted Wetland Systems Vegetated with different plants applied to the treatment of tannery wastewater. Intl. J. Wat. Res. 41(8) 1790-1798.

Chaudry, MA; Ahmad, S; Malik, MT (2007). Supported Liquid Membrane Technique Applicability for Removal of Chromium from Tannery Wastes. Wast. Manage.17(4): 211-218.

Cheesebrough, M (2004): District Laboratory Practice for Tropical Countries. Macmillan Publishing Company, U.S.A. 67-68,137,141,180.

Hussain, F; Saeed, A; Malik, BN; Hassan, M; Mahmood, S (2010). Effect of Tannery Effluents on Seed Germination and Growth of Sun Flower cultivars. Afric. J. Biotechnol. 9 (32): 5113-5220.

Islam, BI; Musa, AE; Ibrahim, EH; Salma, AAS; Babiker, ME (2014). Evaluation and Characterization of Tannery Waste Water. $J$. For. Prod. and Ind. 3: 141150.

Kannan, K; Rajasekaran, G; Raveen, R (2009). Bacterial Analysis of Soil Samples Collected in and around a Sugar Mill in Tamilnadu. J. Ecobiol. 24: 191195.

Mingshu, L; Qiang, H; Dongying; J (2006). Biodegradation of Gallotannins and Ellagitannins. J. Environ. Sci.. 1(1), 2-6. 
Mohammed, A; Sekar, P; George, J (2001). Efficacy of Microbes in Bioremediation of Tannery Effluent. Intl. J. Curr. Res. 3(4) 324-326.

Murugan, K., Saravannati. S. and Amnachalam, M. (2011). Biocompatitle Removal of Tannin and Associated Colour from Tannery Effluent. Research journal of Microbiology.

Mythili, K. and Karthikeyan, B. (2011). Bioremediation of Tannery Effluent and its Impact on Seed Germination. International Journal of Environmental Sciences. 2(8), 40-45.

Nagarajan, P; Ramachandramoorthy, TR (2002). Oil and Grease Removal from Steel Industry Waste Water by Chemical Treatment. J. Ecotoxicol. Environ. Monit. 12: 181184.

Nazer, DW; Al-Sa, RM;Siebel, MA (2006). Reducing the Environmental Impact of the Unhairing and Liming Processes in the Leather Tanning Industry. J Clean. Prod. 14:65-74.

Noorjahan, CM (2014). Physicochemical Characteristics, Identification of Fungi and Biodegradation of Industrial Effluent. J.Environ. Eart. Sci. 4: 3239.

Oyeleke, SB and Manga, BS (2008). Essentials of laboratory practical in Microbiology $1^{\text {st }}$ Edition. Tobest Publishers, Minna, Nigeria. 36-46.

Rajiv, P; Hasna, A; Kumaraji, M; Rajeshwa, S; Sankar, A (2012). Physicochemical and Microbial Analysis of Different Water in Western Tamil Nadir, India. Intl. Res. J. Environ. Sci. 1(1), 32-36.
Selvi, AT; Anjuggam, EA; Deki, AR; Madhans, BO; Kannappam, S; Chemdrasekaran, B (2013). Isolation and Characterization of Bacteria from Tannery Effluent Treatment Plant and their Tolerance to Heavy Metals and Antibiotics. Afri. J. Exptl. Biotechnol. Sci.. 32-34.

Smithi, A; Usha, K (2012). Isolation and Characterization of Chromium Removing Bacteria from Tannery Effluent Disposal Site. Intl. J. Adv. Biotechnol. Res. 3: 644-652.

Sreeram, K J; Ramasami, T (2003). Sustaining Tanning Process through Conservation, Recovery and Better Utilization of Chromium. Res. Conserv. Recycl. 38 (3):185-212. 214.

Suresh, V; Kanthimathi, M; Thanikaivelan, P; Raghava, RJ; Unni, NB. (2001). An Improved Product Process for Cleaner Chrome Tanning in Leather Processing. J. Clean. Prod. 9(6):483491.

Thanikaivelan, P; Jonnalagadda, RR; Balachetran, UN; Ramasami, T (2004). Progress and Recent Trends in Biotechnological Methods for Leather Processing. Tren. Biotechnol., 22:181-188.

Yapici, AN (2008). The Effect of Using a Fungicide along with Bacteriocides in the main Soaking Float on Microbial Load. Afri. J. Biotechnol. 7(21), 3922-3926. 